\title{
Creating Professional Skills through Modern Higher Education
}

\author{
Olga I. Miroshnichenko ${ }^{1} \&$ Yana V. Gaivoronskaya ${ }^{1}$ \\ ${ }^{1}$ Law School, Far-Eastern Federal University, Vladivostok, Russian Federation \\ Correspondence: Olga Miroshnichenko, Law School, Far-Eastern Federal University, Anisimova str, 66-40, \\ 690003 Vladivostok, Russian Federation. Tel: 791-4790-9213. E-mail: olga-star.05@mail.ru
}

Received: June 3, 2014 Accepted: July 5, 2014 Online Published: August 15, 2014

doi:10.5539/ies.v7n9p50 URL: http://dx.doi.org/10.5539/ies.v7n9p50

\begin{abstract}
The research deals with the experience of interdisciplinary investigation and aims at utilizing the data of contemporary career science and the theory of professionalism to enhance the quality of legal education. The authors, who are Professors of the School of Law, Far-Eastern Federal University, propose to introduce the term 'career reserve' into the parlance of science and offer their interpretation of this term in relation to the professional activity of a lawyer. At present, acquiring education is the first stage in the career ladder. To help the students go up the ladder, the modern law school has to educate the students in proper planning of their career and assist them in forming a basic career reserve during their education stage.
\end{abstract}

Keywords: legal education, professionalism, career, career reserve, career planning, important professional skills of a lawyer, acmeological variants of professionalism

\section{Introduction}

One of the primary tasks of contemporary education is creating a professional individual as a subject who can effectively exercise his professional activity and creatively cope with both ordinary and extraordinary situations. The modern higher school is assigned with the task of preparing a graduate who can compete in the job market. That is why the higher schools should provide not only specific knowledge in some sphere but also additional information and skills in the sphere of self-realization, effective communication, planning and constructing a career ladder.

Nowadays, it is not enough for a student to just have specific knowledge or a set of skills in some sphere, like law, medicine, management, IT, etc. A graduate from a modern higher school will have to survive in the midst of severe competition in the job market; therefore, he must be able 'to sell himself', to be liked by the employer or business entrepreneur, to suit professional community and to prove himself as a promising employee and an expert. The experience of graduates' employment demonstrates that the students who had excellent academic record and those who are successful in professional activity are not always the same. Normally, brilliant students with excellent diplomas face problems in securing employment after graduation, and therefore accept low positions, undertake mundane jobs for low or average payment. On the contrary, very ordinary students, with no good academic record make good careers, establish a business of their own, and occupy leading positions.

It is obvious that to succeed in professional and social life, it is not enough to have particular knowledge or practical skills relating to it, such as writing legal documents or interpreting the law. Besides knowledge and skills, an expert should possess certain personal qualities and psychological maturity, which will define his suitability to work in a professional area.

\section{Discussion of a Problem}

\subsection{Situation in Modern Russia}

One should note that, in Russia, the problem of social demand for graduates is created because the first course of the schools of law was filled with yesterday's schoolchildren, who have no experience of life and, in most cases, no common sense even. They have no idea of the practical significance and application of the theoretical knowledge provided by a high school. They generally start thinking seriously about their employment and career only after their graduation or during the last years of their studies. Their poor perception of the social surrounding does not let them avail the resources offered by a higher school to form a career reserve and to plan a career; they thus miss many chances and fail to develop skills and talents necessary for successful social 
realization. To remedy this situation, the students need additional information that can enable them prepare for their future professional requirements. They should be equipped with skills that will let them make a successful career in life. The students should plan their career properly, and design their educational trajectory in such a way that, by the time they complete their graduation, they become qualified to avail of all the opportunities required for making successful career.

Pointing out the problems in modern legal education, many Professors of Law schools and practicing lawyers, stressed the inadequacy of legal education to the requirements of job market. And, in so doing, they refer not only to the Russian education but also to the education in other countries. However, most of their works are limited to just establishing the existence of a problem and searching for the causes (Chkhutiashvili, 2010; Olensky, 2011). But, our approach is to focus on the options available for improving the quality of legal education. In our opinion, the psychology of professional activity and career science have accumulated, over the years, enough information to be used in the academic process of bringing legal education closer to job market requirements.

Thus, social realization of a graduate depends not only on the knowledge of theory and student's practical skills, but on some other factors too. These factors are investigated by such academic courses as psychology and acmeology of professional activity, psychology of professionalism, psychology of labor, and legal psychology (if we speak about lawyers). To determine the factors that contribute to shaping graduates' successful social realization, we would first briefly review some of the provisions of the theory of professionalism extant in Russia.

\subsection{Explaining the Terminology}

First, we define the terminology. Nowadays, two approaches are adopted in interpreting professionalism: sociological and psychological. In sociological approach, execution of an activity is called professional to contrast it with non-professional execution of the same work. The following are some features that are very important for an activity: constant and systematic execution, compensatory or paid execution, and specific training for executing the work (Zhalinsky, 2008). In psychological approach, professionalism means the quality of an activity, mastering of a profession, and high level of skills and effectiveness of the activity. In this sense, the professional activity is carried out by a specialist with high level expertise in his sphere. In our research, we will use the psychological approach, focusing on the merits of a person, which help in achieving significant professional heights.

Modern psychology of employment considers professionalism to be a universal feature, a quality of the labor subject, which lets one do professional work and get success in any sphere, regardless of the type and specifics of the work. Professionalism is not only an individual's new highest level of knowledge and achievement in a particular sphere, but also a certain system of consciousness and psyche of an individual (Derkatch \& Zazykin, 2003).

An individual owning professionalism is called a professional. A profession is a special type of person having a set of qualities that enable him cope with professional challenges better, faster and more effectively than other specialists do. And, the point here is not long term practical experience. Many workers practicing in some sphere for a long time gain professional skills and carry out their work excellently, but they still remain at a low stage of their social and professional ladder. They do not make a career, do not occupy leading positions and do not draw high salaries. On the contrary, there are others having the same level of education and the same or even lesser experience, but they still make an excellent career. Besides, they are not only in demand, but are also out bidden by big companies with lucrative offers, and consequently they occupy leading positions. Why does this happen? According to the modern theory of professionalism, these people possess certain qualities that give them career advantages.

Originally, the theory of professionalism is a part of acmeology (a section in age psychology studying the psychology of maturity, the age of acme, approximately 30-37, 30-40). This defines the specifics of the terminology. The parameters of professionalism in Russian acmeology and in the theory of professionalism are defined by the term 'acmeological invariants of professionalism'. These invariants are the basic qualities and skills of a professional providing high stable efficiency and reliability of an executed activity, regardless of its content and specifics (Derkatch \& Zazykin, 2003). Besides, acmeological invariants of professionalism are represented in inner motivating reasons, which provide an individual active self-development and realization of creativity.

Some scientific results prove that high-level professionals, regardless of the type and the specifics of their professional activity, demonstrate many more developed invariants than what the others, doing the same work, 
show.

Acmeological invariants of professionalism can be divided into general and specific ones. General invariants are the qualities and skills of an individual absolutely independent of the professional activity. Specific invariants reflect, to some extent, the specifics of the professional activity; they are not the same for all professions but only for a type or group of professions. For instance, according to research, the invariants are the same for the specialties of a social (communicative) type feature, such as insight, or social perceptive competence, communicability and communicative skills, a talent to make a psychological influence, etc.

The most important in the theory of professionalism are the general invariants of professionalism and the task of science is to formulate them. At present, the Russian acmeology singles out the following general acmeological invariants of professionalism:

1) The power of an individual (developed will and ability to take responsibility).

2) Developed anticipation (ability to precisely and reliably predict and forecast the situation that can arise in professional activity).

3) A high level of self-regulation (ability to manage one's own state, great working capacity, resistance to stress, constant readiness for emergency and ability to immobilize one's resources when necessary).

4) Ability to make decisions (determination in making decisions, reliability of these decisions, their opportuneness and preciseness, originality and efficacy).

5) Creativity (demonstrated not only by high creative potential, but also by special skills to solve professional challenges originally and effectively).

6) High and adequate motivation for achievements.

In reality, all this means that if a person possesses these abilities, he will succeed in any professional sphere and will enjoy his labor in that profession. It is naturally so because he has the knowledge required for the chosen sphere of activity. Research on the parameters of professionalism is continuing. The task of science is to expose and formulate the acmeological invariants of professionalism, while that of higher education is a different one.

\subsection{Discussing the Problem}

From some points of view, the effectiveness and quality of education can be determined by assessing how many higher school graduates have been successful in making their own career. Awareness of the patterns of professional development should not be the monopoly of a small cohort of scientists in psychology. The advances in modern theory of professionalism must be given due consideration in formulating the academic programs of higher schools, and the programs must also be spread among students of various majors. Otherwise, it is impossible to speak about the effectiveness of professional education.

Nowadays, higher schools are obliged to train a specialist for career planning and to adopt a conscientious attitude towards the process of education. Under the circumstances, career planning is an essential element of social and professional realization of an individual. The advantage of such planning will be the graduate's awareness of what career reserve he needs to get the desired position, what career opportunities are available to him, and how to gain missing resources. This awareness enables a graduate to regard the process of education as the first stage of the career and as a necessary activity to accumulate career reserve.

Career reserve is a new concept, which appears periodically in Russian books devoted to the psychology of professions. This term has not yet been included either in the scientific apparatus of the psychology of professions or in psychology of labor or other sciences relating to the professional activity of an individual. It is used at the sites of employment agencies and in some publications covering the issues of professionalism. At present, the concept of career reserve is more a publicity than a scientific concept. However, we find this term suitable and quite perspective in case it is scientifically worked out and its content is defined more precisely.

Career reserve is a set of resources an individual needs for realizing his professional activity and career making. The bigger a person's career reserve, the further he can move up the career ladder and the greater goals he can achieve. Preparing a comprehensive list of career resources suitable for all types of activity is impossible. This is not only because there is a wide variety of professions in the modern world, but also because the life situation of any person is highly individualistic. In this research, we will make an attempt to describe the elements of career reserve in the sphere of jurisprudence. Nevertheless, the results, with some modifications, can be applied to other professions too.

With some conditionality, career reserve can be split into two types: basic and special. Basic career reserve is a 
combination of resources to be accessed minimally to exercise legal practice. Generally, basic reserve of a person in legal profession means higher education in law, besides real professional knowledge and skills. But, it does not mean that basic reserve is the same for all graduates of higher law schools. First, we should take into account that professional qualification can be both formal and real. Formal professional qualification is confirmed by documents, and it may not reflect the real qualification of a person. For example, after graduating from law school, a person will have a formal qualification of 'a lawyer' (bachelor of law). But, this alone does not guarantee that he can work effectively in legal profession, or that he actually possesses all the necessary knowledge and practical skills required for that profession. Let us consider another example. The agents of law-enforcement bodies are regularly attested and awarded a class rank appropriate to their formal qualification, like 'third class lawyer', 'second class lawyer', 'first class lawyer', etc. Theoretically, a first class lawyer is supposed to be more qualified and more knowledgeable and skillful than second and third class lawyers. In fact, the situation can be altogether different. According to the legislation of the Russian Federation, the basic factor influencing a person's formal qualification is his working experience in the law-enforcement bodies. The longer this experience, the higher is formal qualification. But, in fact, the level of competence and professionalism is defined not only by the length of employment but also by many other factors, like level of complexity and the number of cases on the lawyer's hand, responsible attitude to work, continuous self-education, ability to make business contacts, etc. As a result, a situation is possible wherein the real qualification of a second class lawyer can prove to be higher than that of the first class lawyer. Real professional qualification is actual professional knowledge and a set of practical skills and abilities an employee possesses. Real professional qualification of students and graduates is often quite different. And, the wider range of practical skills a student can acquire during the period of education is what constitutes a student's basic career reserve.

Second, basic career reserve includes necessary and additional (desirable) resources. For instance, complete secondary school education and a diploma of higher law education are the necessary resources, as stipulated by the legislation. But, the level of education, which can differ (either a bachelor of Law or a master of Law), stipulates different starting opportunities of employment. Besides the primary educational program, a student can use various extra courses and programs offered by modern higher schools. Such extra courses and programs may include the following: practical work in the higher school law clinic; additional professional programs in mediation, staff management, accounting or audit; elective courses of foreign languages in the sphere of law; participating in lectures by visiting experts in law; training in overseas higher school; academic research and participating in students' academic conferences and higher school law olympiads, etc. These activities, though not compulsory for a student, form desirable resources for the basic career reserve of a graduate. All these require a student's time, significant effort, high level of self-organization and a sensible attitude towards education as an important stage of a professional activity. This makes us get down to defining the following group of career resources.

Professionally essential personal qualities form another component of additional career reserve. They are the qualities and talents needed for a person, firstly to master a profession and secondly to succeed in professional practical activity (Derkatch \& Zazykin, 2003). These qualities determine a person's professional appropriateness for a given type of work. Professionally essential personal qualities form and develop not only in the course of education but also during professional activity. However, only a few of these many qualities provide an opportunity to master legal knowledge and predetermine the efficacy of education, and those should form in the course of education. For example, among the professionally essential qualities of a lawyer, we can separate out a group of intellectual and a group of organizational qualities. A lawyer has to possess developed intellectual abilities, high level of intellectual development, erudition, good memory, ability for cognitive operations, such as abstract thinking, logical analysis of information, ability to remember and systematize large volumes of information, and extract the main thing, and deductive and critical thinking. These qualities are neither essential for most professions, nor do they influence the professional degree of such professionals as ballet dancers, drivers, riggers, TV-anchors, jewelers, forest-guards, nurses, builders, farmers, cooks, hair-dressers, shop-assistants, etc. But, in the case of lawyers it is not so; they need them compulsorily. Without them, a lawyer can neither get proper legal knowledge, nor can he exercise most kinds of legal work. Students of law schools and practicing lawyers have to deal with a large amount of special information that demands developed organizational qualities. First of all, we speak about self- organization, which requires the ability to exercise effective time-management and to distribute tasks according to their priority. Without organizational qualities, a student can neither cope with the volume of academic load, nor can he use the opportunities of additional education, which are provided by higher schools today. That is why we suggest the inclusion of developed professionally essential personal qualities in the basic career reserve. 
Basic career reserve forms during professional education. The more the knowledge, practical skills and personal business qualities a student can develop, the more career advantages can he have in future.

Special career reserve is a combination of several career resources that are necessary for an individual to grow professionally and to make a career in some sphere. First of all, it includes the resources necessary for a given type of legal activity to meet the high standards stipulated by the legislation. For example, such standards exist for the careers of judges, advocates, professors of law schools, notaries, etc. These resources can include age, length of employment, working experience in a particular sphere or in a particular position, a definite level of education, additional education (training courses), references from professional society, etc. Secondly, special career reserve covers all other resources, which add to the professional advantages of a particular profession in the job market. Other resources may include high qualification in some sphere of activity, availability of unique knowledge and skills, business contacts, additional education (in the major or in a closely related profession), mastering modern computer technologies, training in well-known higher schools and big companies, knowledge of foreign languages, scientific degree, experience in domestic and overseas companies, etc. Special career reserve also includes unique individual qualities of a person, such as acmeological invariants of professionalism, developed business skills, self-education, ability to shape one's own image and to realize self-presentation, communicative skills, administrative skills, high working capacity, resistance to stress, absence of conflict, mastering various communicative techniques, etc.

Summing up, the following are the elements of career reserve in law: level of professional education, qualification, i.e. actual knowledge and related practical skills of a person, business contacts, working experience, references from previous jobs and professional societies, image and reputation in the professional society, documentary proof of advanced training courses, developed acmeological invariants of professionalism, and essential professional and business skills.

Different elements of career reserve form at different stages of career growth. A few works in literature define some career stages. To follow the career reserve formation of a specialist, we adopt a rather simple division of career into periods. For this, we identify six basic stages of career opportunities: preliminary stage (until the age of $25 \mathrm{yrs}$ of age), forming career stage (25-30 yrs of age), advanced career stage (30-45 yrs of age), preserving the career stage (45-60 yrs of age), finishing career stage (60-70 yrs of age) and final career stage (after 70 yrs of age) (Chashin, 2009). Let us look at the first three stages in detail. For most people, the rest of the stages are not connected with the formation of career reserve; they focus on advanced training to maintain their career at a proper level (or lack of professionalism).

The preliminary stage: It covers the period of getting education and the first qualification. During this period, primary basic career reserve accumulates, like getting complete high school education, getting professional education, and searching for the main and perspective job. At this stage, it is reasonable to formulate a preliminary plan of career development.

Forming career stage: It is defined as the period of mastering primary basic professional skills, and forming a qualified specialist. During this period, special career reserve accumulates: undergoing advanced training, getting additional and postgraduate education, gaining quality mastery of a profession, and setting business contacts.

Advanced career stage: During this period, by virtue of the accumulated career reserve, an employee makes a swift jump over the career ladder. This is the period of maximum effort, as well as increased qualification. Very often, this stage 'eats' the whole accumulated career reserve. Consequently, in the career ladder, the employee remains at a level after reaching which his reserve is exhausted.

Career reserve accumulates mostly during the initial career stages, and this limits the performance of a person in the subsequent years. That is why it is necessary to guide the students in proper and timely planning of their career during the sensitive stage of career reserve formation. While studying, it is possible and necessary to develop not only basic but also a part of special career reserve. And, the more the accumulation of the career reserve, the more successful will be social realization of an individual.

Thus, the modern school of law, which focuses on the quality of the provided educational service, will have to address two tasks. The first is to provide the students with a wide range of possibilities to accumulate additional career reserve, like programs of additional education, training courses, electives, conferences, etc. The second is to ensure the spread of contemporary knowledge of the theory of professionalism and career science among the students. Knowledge of the parameters of professional activity, professionally essential qualities, career planning, professional crises and prevention of professional deformation in modern world is as necessary a part of professional education as are the exclusively professional knowledge and skills of their majors. 
These ideas stipulated the fact that during the last decades Russian higher schools have included in their courses programs in the theory of professionalism. We've considered this issue having law as an example as it's very close to the researches, but this is the tendency of many humanities. In the last ten years, the Law School of the Far-eastern Federal University has conducted the following courses: 'Introduction into jurisprudence', 'Psychology of professional activity', 'Conflict research in professional activity', 'Professional activity of a lawyer'. The present course, 'Professional activity of a lawyer', covers the features of the profession, introduces the peculiarities of legal profession, and presents the basics of modern theory of professionalism, as also the concept of professional self-determination and self-actualization. Besides, it gives information about the concept and types of career in the sphere of law as well as about planning a career.

\section{Conclusion}

So, a modern university must provide its students information about the modern theory of professionalism and help them develop acmeological invariants of professionalism. A graduate must be in a position to exercise self-presentation, and to create his own image of a professional, in tune with the expectations of his professional society. He should possess developed communicative skills and be capable of finding a common ground with different people so as to succeed in convincing people and expressing his thoughts properly. He must be ready to deal with stress and conflict situations and be capable of maintaining a high working capacity. A modern specialist is supposed to be ready for self-education and to have the ability to find necessary information very fast and thus improve his qualification. He has to plan his own activity, arrange his priorities and formulate the tasks. If he is planning to take some administrative position or to conduct his own business, then he should have the skills of organizing and planning group activity involving distribution of the duties and controlling their execution. All these are universal skills, which are equally needed for the careers in law, logistics, management, commerce, beauty industry, IT, medicine and other spheres. That is why a modern higher school cannot restrict itself to teaching only specialized disciplines. Knowledge of law or medicine can prove ineffective if a person cannot find his own social niche or suitable employment or if he cannot establish contacts with colleagues, business partners and authorities. These factors underscore the importance of teaching compulsory courses of the theory of professionalism, psychology of professional activity, conflict research, psychology of social groups, business communication, image science, the art of negotiating and other programs.

\section{References}

Chashin, A. N. (2009). Professional career of a lawyer (pp. 100-102). Moscow.

Chkhutiashvili, N. V. (2010). New requirements of the job market to fresh lawyers. Legal Education and Science Journal, 4.

Derkatch, A., \& Zazykin, V. (2003). Acmeology. St. Petersburg.

Olensky, S. F. (2011). The Increase In Quality of Law Education: Issues of Effectiveness of Forming Anti-corruption Thinking. Lawyer journal, 19, 43-46.

Zhalinsky, A. E. (2008). Introduction into jurisprudence-Professional activity of a lawyer (pp. 56-61). Moscow: Prospect.

\section{Copyrights}

Copyright for this article is retained by the author(s), with first publication rights granted to the journal.

This is an open-access article distributed under the terms and conditions of the Creative Commons Attribution license (http://creativecommons.org/licenses/by/3.0/). 